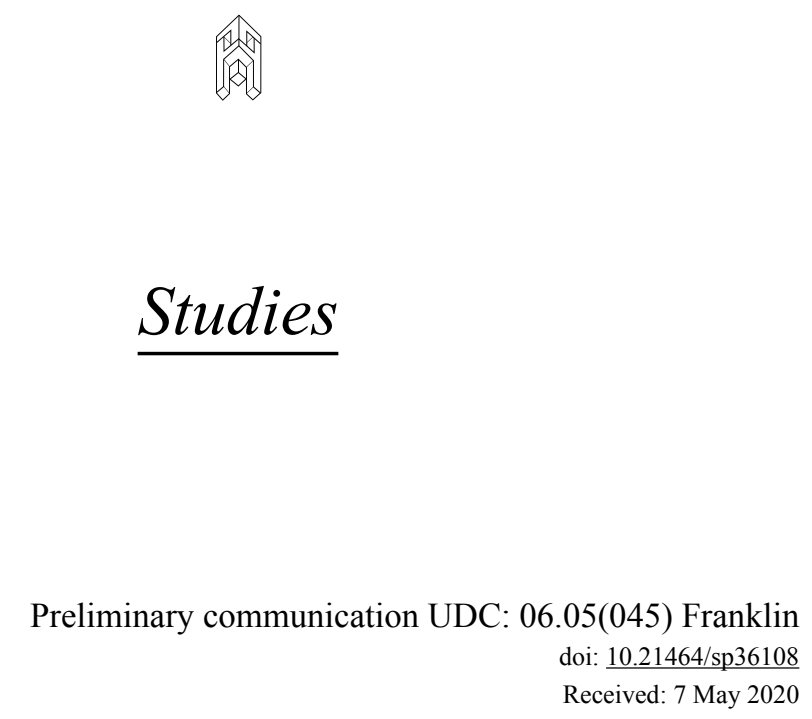

Toni Buterin, ${ }^{1}$ Iva Rinčić, ${ }^{2}$ Amir Muzur ${ }^{3}$

1,2,3 Sveučilište u Rijeci, Medicinski fakultet, Braće Branchetta 20, HR-51000 Rijeka

${ }^{2,3}$ Sveučilište u Rijeci, Fakultet zdravstvenih studija, Viktora Cara Emina 5, HR-51000 Rijeka

${ }^{1}$ toni.buterin@uniri.hr, ${ }^{2}$ iva.rincic@medri.uniri.hr, ${ }^{3}$ amir.muzur@medri.uniri.hr

\title{
Frankly Revisiting Franklin - How a 60-Year-Old Case Might Help Prevent Future Injustices
}

\begin{abstract}
The role of Rosalind Franklin, chemist and X-ray crystallographer, in one of the most important discoveries of the 20th century - the discovery of the DNA helical structure - has long been debated. Although numerous protagonists have provided different versions of the events preceding Watson and Crick's famous paper in journal Nature in April 1953, it is nevertheless evident that a serious breach of ethical research conduct was committed. By analysing the controversy of Franklin's deserved but missed Nobel Prize, the authors of the present paper suggest that the Nobel Prize nomination and awarding procedure might be revised to avoid Franklin-like injustices in the future. According to the authors, this might be achieved by returning to Alfred Nobel's original idea of awarding the prize "to those who, during the preceding year, shall have conferred the greatest benefit to humankind" and/or by allowing a deceased person to be both nominated and awarded.
\end{abstract}

\section{Keywords}

Rosalind Franklin, research ethics, Nobel Prize, DNA history, injustice

\section{Introduction}

On 25 April 1953, three papers were published in Nature, bringing the "fundamentally beautiful" (White, 2001; Rapoport, 2002) structure of DNA to the public's attention and starting a DNA revolution. The most famous of these papers is the article by James Watson and Francis Crick (1953). Along with Watson and Crick's, two papers, one by Maurice Wilkins, Alec Stokes and Herbert Wilson (1953), and the other by Rosalind Franklin and Raymond Gosling (1953), were published, showing that the Watson and Crick model was consistent with their X-ray diffraction patterns (Fuller, 2003). Before 1950 , scientists already had some knowledge of heredity due to Gregor Mendel and Oswald Avery's work but almost no knowledge of the molecular basis of heritage. By 1952, much had been learnt about DNA, including its exclu- 
sive role as genetic material storing practically all the information needed to create a living being. However, it was not yet known what the exclusive DNA molecule looked like and how it performed its amazing function. The double-helical structure of the DNA molecule, a twisted ladder with base-pair rungs, was deciphered in 1953. The individuals most commonly associated with this remarkable accomplishment were James Watson and Francis Crick. Maurice Wilkins played a role as well, sharing with Watson and Crick the 1962 Nobel Prize for Physiology or Medicine. Yet, there was one other person whose truly essential contribution to that discovery was not recognised by the Nobel Committee in 1962: ${ }^{1}$ her name is Rosalind Franklin.

\section{Highlights of Franklin's Biography}

Fully aware that a number of excellent biographies of Rosalind Franklin exist, we shall try to focus only upon those elements of her life story that explain Rosalind Franklin's scientific path and her character, as well as the events that are surrounded in controversy.

Rosalind Elsie Franklin was born in London on 25 July 1920, the second of five children, to a wealthy Jewish family. Her ancestors had lived in England since 1763, and her grandparents lived in an upper-class English style. Rosalind's father, Ellis Franklin, and her mother, Muriel Waley, had been raised in a tradition of public service and philanthropy. Rosalind's father was a banker, taught science as a volunteer at the Working Men's College and helped numerous Jews escape from Nazi Germany. In London, Rosalind attended St. Paul's Girls' School, an academically rigorous day school for the daughters of well-to-do families. Because of the excellent physics and chemistry classes offered at St. Paul's, at the age of fifteen, Rosalind decided to become a scientist. She took and passed the entrance examinations for the study of physical chemistry at Cambridge University but her father, strongly disapproving of women's university education, refused to pay for her to attend (on the specific obstacles encountered by women when embarking on a career of scientific research, among several available texts, one should consult the crucial study by Margaret W. Rossiter (1982) or, for instance, Sally Gregory Kohlstedt and Helen Longino's paper (1997). However, after her mother announced that she would pay out of her own family money, her father backed down and agreed that he would pay after all. The beginning of World War II in September 1939 precipitated another argument between Rosalind and her father, as he wanted her to quit her education and do voluntary defence work. However, luckily for Rosalind, the British government made it clear that all science students should finish their education first. After receiving her Cambridge degree in 1941, Franklin spent a year researching physical chemistry with the future Nobel Prize-winning chemist Ronald Norrish, who encouraged her to begin studying the physical structure of coals and carbon for the British Coal Utilisation Research Association.

\footnotetext{
"In her laboratory, Franklin focused on a large and important wartime problem: how to use England's coal and charcoal more efficiently. In a series of elegantly executed experiments, she discovered the structural changes that occur when coal and carbons are heated and showed why some heated carbons turn into graphites as their molecules form parallel layers that slip and slide apart." (McGrayne Bertsch, 1998: 308)
}

In 1945, Rosalind Franklin received her PhD in physical chemistry, which made her, at the age of 26, a recognised industrial chemist. Soon, Franklin 
realised that she would need to master the developing X-ray crystallography in order to understand the material that the universe was made of. Crystallography is a branch of physics, a technique used to reveal the position of atoms within matter. In 1951, X-ray crystallography was a revolutionary way to view the 3-dimensional structure of molecules. This method requires the chemist to remove the DNA from a cell painstakingly and then convert it into a crystal form. The next step is to shine X-rays into the crystal. These X-rays are diffracted by the atoms in the crystal and can produce an image of the actual 3-dimensional position of the atoms in the crystal of a molecule (Rapoport, 2002). With the help of her friend Adrienne Weill, in 1947, Franklin started to work in Paris at the Laboratoire Central des Services Chimiques de l'Etat but decided to go back to England after four years. ${ }^{2}$ In 1951, Franklin went to work as a research associate to John Randall ${ }^{3}$ at King's College in London. Randall's second-in-command was Maurice Wilkins, who was supposed to become Franklin's colleague in discovering the structure of DNA. ${ }^{4}$ Franklin and Wilkins should have collaborated (J. Randall had probably failed to present a clear "job description"), but Wilkins showed intolerance towards Franklin, as his laborious progress towards the structure of DNA was rudely disturbed by her arrival. ${ }^{5}$ Franklin, already an established researcher, had good reason to feel that she had been misled by John Randall's letter about the degree of independence she could expect in her X-ray diffraction studies of DNA. Equally, Wilkins felt outraged by being abruptly excluded with no prior notice from Randall. With his experience of directing an industrial research laboratory and previous technological war-directed research, John Randall

1

Neither was she mentioned in the winner's ceremony speech of Watson and Crick (Glynn, 2012).

2

Rosalind's sister wrote about Rosalind's four beautiful and happy years in "far and away the best city in the world", as she had written to her sister. While in Paris, Rosalind wrote: "I find life interesting." and "I have good friends and I find infinite kindness and good will among the people I work with." (Glynn, 2012: 1094).

\section{3}

"Physicist John Randall, who invented the key to radar in World War II, formed an interdisciplinary team of physicists, chemists, and biologists to study living cells at King's College in the University of London. The team knew that DNA (deoxyribonucleic acid) carries genetic information from one generation to another. It was also known that atoms of many proteins are shaped like a helix, that is, like a spiral staircase or an extended coil of springs. But no one understood DNA's structure or dreamed that it would explain heredity." (McGrayne Bertsch, 1998: 311) Writing to Franklin before she came to his laboratory, Randall made it clear that she would be working alone on a new topic as an expert analysing X-ray photographs of DNA molecules.
Wilkins had been Randall's graduate student even before World War II and had worked on the atomic bomb. When he returned from his holiday, he supposed Franklin had been hired as a high-class technical assistant to supply the rest of the team with experimental data, and his attitude towards Franklin played a crucial role in Franklin's life in the laboratory. "Rosalind and Wilkins were not only alienated, but hostile, and sometimes actively so, and this is sufficiently unusual to be unaccountable, unless one assumes that something in the surrounding circumstances was extraordinarily unpropitious." (Sayre, 2000: 95)

Wilkin's interest and contacts with other scientists are explained by Wilkins himself in his book The Third Man of the Double Helix: The Autobiography of Maurice Wilkins. Chapter IV also explains the nature of his relationship with Rosalind Franklin, describing the growing polarisation between them in their different approaches to seeking the structure of DNA (Gosling, 2003). 
felt that the laissez-faire ethos of university research ought to be superseded. ${ }^{6}$ However, almost a year before the end of the three-year fellowship, to widespread relief at King's College, Franklin left the group to join JD Bernal's research group at Birkbeck College (Fuller, 2003). ${ }^{7}$

\section{Uncovering the Structure of DNA}

In the early 1950s, two laboratories in England were working to uncover the crystal structure of biological materials: King's College in London, studying the structure of DNA, and the Cavendish Laboratory in Cambridge, studying the structure of proteins. Research findings by Rosalind Franklin, proving that the DNA molecule had an ordered structure, helped to put the King's team far ahead in the DNA race. At the same time, Maurice Wilkins from King's College and James Watson (Cavendish Laboratory) became friends, not only due to their interest in science but also because they shared a similar impression of Rosy, as they used to call Rosalind Franklin. ${ }^{8}$ At the end of 1951, Franklin gave a talk at King's College about her work, and the talk was also attended by James Watson. At this point, Franklin knew much more about the structure of DNA than either Watson or his colleague from the Cavendish lab, Francis Crick. By the spring of 1952, Franklin was the only person working on DNA full time. In May 1952, after 62 hours of exposure, she obtained a vivid photograph of DNA in two forms: a "dry or low humidity" form and a "wet or high humidity" form (also known as the "A and B forms"). ${ }^{9}$ Her clear X-ray photograph of the wet form of DNA was revolutionary because she had taken a photograph looking down the length of a DNA molecule, demonstrating that the structure was a helix or twisted ladder. Forty-six years after viewing Franklin's photograph, James Watson still recalled it vividly:

"I was shown Rosalind Franklin's X-ray photograph, and whoa! It was a helix! And a month later, we had the structure." (Rapoport, 2002: 120)

Even today, this photo, known as "Photograph 51", is regarded as one of the most beautiful X-ray photographs ever taken. Franklin put the photo in a drawer and continued with her work. ${ }^{10}$ At the same time, the split between Wilkins and Franklin was widening rapidly. Wilkins started to duplicate Franklin's data, passing them to James Watson and Francis Crick. ${ }^{11}$ Early in 1953, the balance in the pace of advance shifted from Franklin to Crick and Watson. Franklin was not sure about DNA structure, as she still had no evidence and did not have a finished analysed structure. At the same time, Watson and Crick were, despite having produced no experimental evidence at all, actually quite close to uncovering the DNA molecule. At the end of January 1953, Watson came to King's College to visit Wilkins. James Watson describes the now-famous scene:

\footnotetext{
"Walking down the passage [...] [Wilkins] revealed that [...] he had quietly been duplicating some of Rosy's and Gosling's [Rosalind's assistant] X-ray work [...]. Then the even more important cat was let out of the bag: since the middle of the summer Rosy had had evidence for a new three-dimensional form of DNA [...] When I asked what the pattern was like, Maurice [Wilkins] went into an adjacent room to pick up a print of the new form they called the 'B' structure. The instant I saw the picture my mouth fell open and my pulse began to race. The pattern was unbelievably simpler than those obtained previously [...] and Maurice told me he was now quite convinced that she [Rosalind Franklin] was correct." (Watson, 2001: ch. 23)
}

Watson and Crick had been working with five-year-old photos of DNA and had had no idea of its two forms, wet and dry. The picture told them the basic 
dimension of the helix. ${ }^{12}$ Without knowing she was already out of the race, on 10 February 1953, Franklin took her photograph of the wet B-form out of the drawer and started to analyse it and to build models to help visualise her mathematical calculations. Sketching the A-model first, she almost figured out the key concept that Crick had already discovered: that the outside chains march up and down outside the molecule. In her laboratory notebook, she drew the dry A-form as a figure of eight - one chain up and one chain down. At that point, she was not thinking in terms of the helix for the A-form, although the spiral S-shape virtually assumes a helix. The helix was visually elegant, but biologically the most important point about DNA is the base pairing, for this is the code that passes individual characteristics on to succeeding generations. Crick's memory is that he suggested the base pairing of DNA in February, but given the records of Watson, it seems he figured out that part the next day.

"Using evidence uncovered by the biochemist Erwin Chargaff, Watson knew that pairs of bases form the steps of the helical staircase. Building models of the molecule showed him that each step consists of a particular pair of bases: adenine with thymine and guanine with cytosine [...]. To reproduce itself, DNA simply divides in half longitudinally, leaving one outside chain attached to one of the bases; the complementary base is attached to the opposite chain. Finally, each chain makes its complement and recombines. This incredibly simple mechanism explains

As in other examples, such a "practice of deliberate abstention from direction and interference with individual freedom of choice and action" (Merriam-Webster Dictionary definition of laissez-faire) was based on trust which, obviously did not exist within the laboratory.

7

Today, Franklin would have the opportunity to address various research ethics offices and committees, but at that time she had no other recourse but to leave.

James Watson's 1968 autobiographical work, The Double Helix, describes Franklin as follows: "By choice she did not emphasize her feminine qualities. Though her features were strong, she was not unattractive and might have been quite stunning had she taken even a mild interest in clothes. This she did not. There was never lipstick to contrast with her straight black hair, while at the age of thirty-one her dresses showed all the imagination of English bluestocking adolescents." (Watson, 2001: ch. 2) Francis Crick later recalled that Watson's harsh view of Franklin was influenced by Wilkins and that all the ideas that Watson put down in his book The Double Helix he had got from Maurice Wilkins. The portrait of Rosalind Franklin in The Double Helix has angered many women ever since (Judson, 2001).

9

The existence of the A or B form depends on its level of hydratation (McGrayne Bertsch, 1998).
10

That spring, the US State Department refused to issue a passport to Linus Pauling, who had also been working on DNA. He had been invited to speak at a protein conference in London, but due to an accusation that he was a communist, he did not go to England. Pauling realised later that the government's travel ban had prevented him from seeing Franklin's data. Had he done so, the two of them might have discovered the structure of DNA together. If so, Pauling might have won three Nobel Prizes instead of two (curiously, L. Pauling was awarded the Nobel Prize for Peace in 1962 but received the award a year later and did not meet Wilkins, Watson and Crick (https://www.nobelprize.org/prizes/ peace/1962/summary/). This was the second time that Franklin missed the opportunity to acquire a collaborator and so continued to work alone (McGrayne Bertsch, 1998).

11

Modern practices, including the keeping of detailed laboratory diaries, sharing ideas at laboratory meetings, etc., try to prevent such dishonesty.

12

As Wilkins complained later: "They could not have gone on to their model, their correct model, without the data developed here. They had that - I blame myself, I was naive - and they moved ahead $[. .$.$] . We were scooped, I$ don't think quite fairly." (McGrayne Bertsch, 1998: 319) Defending himself in 1992, Watson countered: "I didn't feel guilt. The picture was old. I'm sure Maurice wouldn't have shown it to me if it had been only two weeks old.” (McGrayne Bertsch, 1998: 319) 
how genetic information can pass from generation to generation for thousands of years without change. Triumphantly, Watson and Crick showed their model to colleagues and wrote to their friends. Strangely, neither told Franklin or Wilkins about it, despite the help they had received from Franklin's data." (McGrayne Bertsch 1998: 320-321)

By the end of February, Franklin knew that the B-form was helical and that it was made of two chains. At the beginning of March, she and her assistant Gosling wrote a paper summarising what they knew about "photograph 51". ${ }^{13}$ By the time her manuscript had been typed, it was already 17 March 1953. The next day, the editor of Nature magazine called: Watson and Crick had solved the structure of DNA and submitted an article on 6 March. The editor thought Wilkins and Franklin might like to contribute accompanying articles, so they did.

On 25 April 1953, Nature published the article by Watson and Crick faster than it had ever published any paper before. One of the most popular science articles ever published is only a thousand words long, offers a hypothesis without proofs, cites no authorities or historical records, and does not credit any other scientist whose work helped the discovery. ${ }^{14}$

\section{Is There a Scientists' Code of Honour?}

Franklin's famous X-ray photograph clearly showed the diffraction pattern of a helix for the first time ever. Then, it followed that Wilkins, who had taken Franklin's photograph from her drawer without her knowledge or permission to show it to Watson, along with Watson and Crick, who had used Franklin's work, at the very least were ethically bound to credit her properly. ${ }^{15}$ This is because Franklin's X-ray allowed them to properly model the DNA molecule structure (as a helix with the phosphates on the outside) months before they would have deduced the correct structure on their own. In 1962, Crick, Watson and Wilkins received the Nobel Prize for Physiology or Medicine. Rosalind Franklin had already been dead for four years. She had died on 16 April 1958 from ovarian cancer at the age of only 37. Was Franklin's lethal disease due to her well-known lack of concern with X-ray radiation and not wearing protective lead aprons (Maddox, 2002)? This intriguing question has remained a matter of speculation.

It is true that the notions of "research integrity" and "research misconduct" must have been perceived differently and less clearly defined in the middle of the 20th century than they are today. In the United States, a southern honour code has been adopted by many universities since the 18th century, initially based upon an individual sense of honour and later upon an institutional one. The code mostly stressed the orientation towards five fundamental values: honesty, trust, fairness, respect, and responsibility (cf. Yakovchuk, 2011). In 1985, the Health Research Extension Act was enforced, requiring universities to develop mechanisms to fight scientific misconduct (Steneck, 1994). In the United Kingdom, modern universities clearly define "unacknowledged appropriation of the work of others" as misconduct in research (University of Oxford 2020). Even if not defined in an equally straightforward way and thus institutionalised, taking someone else's results without permission had been forbidden in England since the passing of the 1710 copyright law. Thus, an elementary code of honour existed in science even at the time of discovering the structure of DNA. ${ }^{16}$ 
There is no question about Franklin's crucial contribution to the discovery (Maddox, 2002), which was credited even by Francis Crick, ${ }^{17}$ who at the same time prepared Wilkins's nomination letters. ${ }^{18}$ The question about the merit of Maurice Wilkins sharing the Nobel Prize with Watson and Crick, however, still remains. Although Crick clearly gives priority to Franklin, he credits Wilkins with initiating "the only serious X-ray work on DNA up to 1953", being "the first person to realise that DNA might be helical" (Zallen, 2003: $15)$, and with carrying the work on DNA from the time Franklin left King's College.

In a recent interview in the Scientific American magazine, Watson himself suggested that it might have been a good idea to give Wilkins and Franklin the Nobel Prize for Chemistry, and him and Crick the Nobel Prize for Physiology or Medicine - in this way, all four would have been honoured (Watson, 2003).

\section{The Nobleness of the Nobel Prize Instead of a Conclusion}

Rosalind Franklin died in 1958. As a rule, only living people can be nominated for the Nobel Prize. Therefore, the 1962 prize was out of the question

13

Some authors claim that Franklin's assistant, Raymond Gosling, had passed the B-tape patterns to Wilkins, who had finally shown them to Watson on his crucial visit to King's College at the end of January 1953. Before their interest in the B-pattern, Franklin and Gosling unsuccessfully concentrated their efforts on an analysis of the A-pattern. Although it is widely believed that Franklin supported an anti-helical view of DNA structure, according to Aron Klug's evidence, from his access to Franklin's notebooks and draft papers, in the final months before the discovery, Franklin was working on the assumption that the B-pattern was helical (Fuller, 2003).

14

Watson and Crick only thanked physical chemist Jerry Donohue for his constant advice and criticism. At the same time, it is beyond dispute that without Franklin's photograph, the two of them would have been left with their unverified model of the DNA molecule (Rapoport, 2002).

\section{5}

The credit Watson and Crick gave to Franklin was far from proper: "We have also been stimulated by a knowledge of the general nature of the unpublished experimental results and ideas of Dr. M. H. F. Wilkins, Dr. R. E. Franklin and their co-workers." (McGrayne Bertsch, 1998: 322)

16

One might argue that, even in our time with highly institutionalised research ethics, abuses still occur. This means that one should never give up working on the improvement of the ethical conduct of researchers.
17

In an ironic twist of fate, several years before she died, Franklin struck up a friendship with Francis Crick and his wife. During her illness, Franklin even stayed as a guest in their home. "After her death, when Crick was asked whether, then, he believed that no one at King's would ever have solved the problem [of the structure of DNA], Crick said, 'Oh, don't be silly. Of course Rosalind would have solved it $[. .$.$] . With Rosalind it was only a$ matter of time." (Klug, 1968: 808, in: Rapoport, 2002: 123)

18

Crick writes about Wilkins as follows: "On the matter of Maurice Wilkins, I think his contribution was two fold. He initiated the careful X-ray work on DNA, and since 1953 has done numerous extensive, accurate and painstaking studies on it. It is true that he has worked rather slowly, but then hardly anybody else has done anything. However, the data which really helped us to obtain the structure was mainly obtained by Rosalind Franklin, who died a few years ago [...]. Nevertheless, for the last eight years Maurice has done all the hard work on the problem and that should be recognised." The document is a letter, dated 31 December 1961, and an accompanying overview of the DNA work, from Crick to his friend Jacques Monod, was evidently intended to provide Monod with material to prepare a nomination letter for the Nobel Prize (Zallen, 2003: 15). 
for Rosalind Franklin. However, she might have been a nominee while she was still alive. According to the rules of the Nobel Foundation Statute $(\S 10)$, fifty years after a particular prize has been awarded, the archives concerning the nominees are released. Therefore, since 2008, it has become possible to see whether Rosalind Franklin was ever a nominee for the Nobel Prize during her lifetime. According to the information we obtained from the Nobel Committee for Physiology or Medicine of the Karolinska Institute in Stockholm, it appears that Rosalind Franklin was never nominated for the Nobel Prize. ${ }^{19}$ In January 1992, the English Heritage Society placed a memorial plaque outside Franklin's apartment at 22 Donovan Court, Drayton Gardens in the Kensington neighbourhood of London. The inscription says:

"Rosalind Franklin, 1920-1958, pioneer of the study of molecular structures including DNA, lived here 1951-1958."

On 1 March 2004, Finch University of Health Sciences / The Chicago Medical School changed its name to the Rosalind Franklin University of Medicine and Science.

The question was and still is: is that enough? No, it is far too little. Sixty years after Rosalind Franklin's death, to at least partially rectify the injustice done to this extraordinary scientist, the truth has to be told in schools and textbooks. The question is: should Rosalind Franklin have been awarded the Nobel Prize? Even if it has been said that Franklin "never made the inductive leap" (Maddox, 2002: 202), it is also more than clear that the experimental work preceding the DNA-structure discovery was done entirely at King's College laboratory (where Franklin had been working) and that Watson and Crick had had "inspired insight" into this work (Maddox, 2002: 207-208). ${ }^{20}$ Another, even thornier question might be: should Watson, Crick and Wilkins have been awarded the prize when they had violated the principles of the integrity of research? The ethical considerations policy of the Nobel Prize Committee in the process of evaluating nominations has always been quite unclear, with several cases casting a shadow on certain awards and awardees (cf. António Egas Moniz and the frontal lobotomy).

Last but not least: why was the Nobel Prize not awarded to Franklin before 1962? The importance of the DNA-structure discovery was immediately recognised (Darlington, 1955; Donohue, 1956). Was someone, abhorring the idea of Franklin sharing the prize, aware of Franklin's serious health problems, which began in August 1956 (Maddox, 2002)? ${ }^{21}$ What was the real motive for Crick's pushing the nomination of Wilkins in 1961? Was it a tribute to Franklin's laboratory or to Wilkins's silence?

If we really would like to avoid similar violations of research ethics in the future, we should seek a revision of the Nobel Prize nomination and awarding procedure beyond the changes introduced in recent years. In his excellent book of 2002, ${ }^{22}$ István Hargittai analyses in depth the deficiencies in the Nobel Prize nomination process (oversights in the process of deciding who gets a prize; people who did work that was clearly "Nobel class" but never received the award; people who could have shared the prize that was awarded, cf. Hargittai, 2002), some of which may well apply to the Franklin case (the "fourth person omission", etc.). ${ }^{23}$

Some of these deficiencies clearly are due to human imperfection and can never be overcome. What we suggest here is to return to Alfred Nobel's original idea of awarding the prize "to those who, DURING THE PRECEDING 
YEAR, shall have conferred the greatest benefit to humankind" (Statutes of the Nobel Foundation, $\S 1$ ). In this way, the Franklins of the future might have better chances, and no one could ever wait for someone to disappear from this world in order to launch the nomination procedure. Of course, one might argue that a shorter time window might mean rushing to a biased judgement which is particularly dangerous for women and minorities - but it also might mean avoiding the specific situation Rosalind Franklin was the victim of.

Another change we suggest concerns paragraph $\S 4$ of the Statutes of the Nobel Foundation, namely that

“... work produced by a person since deceased shall not be considered for an award. If, however, a prize-winner dies before he has received the prize, then the prize may be presented."

We feel that a much better and fairer solution would be if a deceased person might be both nominated and awarded (especially if paragraph 1 remains as it is). In such cases, the Nobel Prize might encompass just the Diploma and the Medal but not the financial aspect. That changed, the Nobel Prize might become a corrective and not a hardener for non-ethical behaviour in science. This would be particularly valuable if the Nobel Prize awarding procedure took ethical considerations more seriously.

In this way, other "unlucky" scientists, for instance, Schaudinn, the discoverer of the syphilis agent, might also have properly been honoured. It is well known that women encounter significant difficulties within the scientific establishment (Cole, 1987; Le-May Sheffield, 2004; Rosser, 2008). As stressed by Long and Fox:

"Women generally receive fewer resources and recognition than men for comparable productivity. This leads to the conclusion that stratification in science, or the concentration of women and minorities in the lower ranks and at less prestigious institutions, cannot fully be justified by the assumption that impersonal, universal criteria are equitably applied." (Long \& Fox, 1995: 45-71)

19

For this information, we thank very much A.M. Jörnvall, Administrator at the Nobel Committee for Physiology or Medicine, Karolinska Institute, Stockholm, Sweden.

\section{0}

There is a possibility that she would have been excluded from the prize even if she had not died before 1962. The reason is that the Nobel Foundation Statute $(\S 4)$ has a rule that only a maximum of 3 people can share the prize. After 1962, Chargaff, a biochemist who discovered the rule of base pairing seemed to withdraw from the laboratory (Christy, 2004). The question without an answer is: what would have happened if she had lived? Maybe if her illness had not taken her life, the world would have had another female Nobel Prize winner, although not necessarily for DNA research. She also did research on viruses, and inspired a number of scientists to follow in her footsteps. Maybe she would have been awarded the prize along with Aaron Klug, with whom she collaborated on his "development of crystallographic electron microscopy and his structural elucidation of biologically important nucleic acid-protein complexes" (Norrby, 2013: 357)

21

Typically for the time, Franklin did not pay much attention to wearing protective gear, which is today required in laboratories working with radiation.

22

Of course, this book is not the only critique of Nobel Prize "absurdities" (cf. the article by Yong in 2017).

23

A slight possibility exists that Franklin and Gosling's paper in the 1953 edition of Nature was not recognised because if it had been, it would have involved the "problem of the 4th nominee". 
The Nobel Prize committee has become aware of this shortcoming and has tried to remedy it (cf. Rathi, 2017). Even Alfred Nobel's will has been retranslated with this intention (replacing "mankind" with "humankind"). ${ }^{24}$

If we add these difficulties to the general competitive atmosphere typical of scientific communities (a reward system based on the priority of discovery, or being first to publish, the incentive structure of science being driven by reputation determined by the peer reviews of other scientists, etc. - Merton, 1973; Zuckerman, 1996), we start to understand the extremely laborious path a woman has to follow in order to work in science (in particular, sexual harassment has to be emphasised; cf. Johnson et al., 2018). What we have sought to stress in this paper is that the case of Rosalind Franklin does not just involve one of these obstacles: we might discuss the Franklin case within the framework of impaired gender relations, scientific ethics violation (Merton, 1968), or even anti-Semitism, but this would shed light only upon a part of the problem. These general trends resulted in the fact that some extremely non-ethical behaviour has overshadowed the glorious story of the discovery of the helix, and that the injustice has never been rectified due to the deficient Nobel Prize nominations and awarding procedures. ${ }^{25}$

\section{References}

Christy, Nicholas (2004): "Faculty Remembered: Erwin Chargaff 1905-2002", Columbia University $P \& S 24$ (2004) 1, pp. 1.

Cole, Jonathan R. (1987): Fair Science: Women in the Scientific Community, Columbia University Press, New York 1987.

Darlington, C. D. (1955): "The chromosome as a physico-chemical entity", Nature 176 (1955), no. 4494, pp. 1139-1144, doi: https://doi.org/10.1038/1761139a0.

Donohue, J. (1956): "Hydrogen-bonded helical configurations of polynucleotides", Proceedings of the National Academy of Science of the USA 42 (1956) 2, pp. 60-65, doi: https://doi.org/10.1073/pnas.42.2.60.

Franklin, Rosalind Elsie; Gosling, Raymond George (1953): "Molecular configuration in sodium thymonucleate", Nature 171 (1953), no. 4356, pp. 740-741, doi: https://doi. org/10.1038/171740a0

Fuller, W. (2003): "Who said 'helix'? Right and wrong in the story of how the structure of DNA was discovered", Nature 424 (2003), no. 6951, pp. 876-878, doi: https://doi. org/10.1038/424876a.

Glynn, Jenifer (2012): "Remembering my sister Rosalind Franklin", The Lancet 379 (2012), no. 9821, pp. 1094-1095, doi: https://doi.org/10.1016/s0140-6736(12)60452-8.

Gosling, Raymond (2003): “Completing the helix triology”, Nature 425 (2003), no. 6961, p. 901, doi: https://doi.org/10.1038/425901a.

Hargittai, István (2002): The Road to Stockholm: Nobel Prizes, Science, and Scientists, Oxford University Press, Oxford.

Johnson, Paula A.; Widnall, Sheila E.; Benya, Frazier F. (eds., 2018): Sexual Harassment of Women: Climate, Culture, and Consequences in Academic Sciences, Engineering, and Medicine, The National Academies Press, Washington.

Judson, Horace Freeland (2001): "Honest Jim: the sequel", Nature 413 (2001), no. 6858 , pp. 775-776, doi: https://doi.org/10.1038/35101634.

Klug, Aaron (1968): "Rosalind Franklin and the Discovery of the Structure of DNA", Nature 219 (1968), no. 5156, pp. 808-810, doi: https://doi.org/10.1038/219808a0.

Kohlstedt, Sally Gregory; Longino, Helen (1997): “The Women, Gender, and Science Question: What Do Research on Women in Science and Research on Gender and 
Science Have to Do with Each Other?", Osiris 12 (1997), pp. 3-15, doi: https://doi. org/10.1086/649263.

Le-May Sheffield, Suzanne (2004): Women and Science: Social Impact and Interaction, ABC-CLIO, Oxford.

Long, J. Scott; Fox, Mary Frank (1995): “Scientific careers: universalism and particularism”, Annual Review of Sociology 21 (1995) 1, pp. 45-71, doi: https://doi.org/10.1146/annurev. $\underline{\text { so.21.080195.000401. }}$.

Maddox, Brenda (2002): Rosalind Franklin: The Dark Lady of DNA, Harper Collins, New York.

McGrayne Bertsch, Sharon (1998): "Rosalind Elsie Franklin", in: Sharon McGrayne Bertsch (ed.), Nobel Prize Women in Science - Their Lives, Struggles, and Momentous Discoveries, Joseph Henry Press, Washington D. C., pp. 303-331.

Merton, Robert King (1968): Social theory and social structure, Free Press, New York.

Merton, Robert King (1973): The Sociology of Science, University of Chicago Press, Chicago.

Nobel Media AB (2011): "Statutes of the Nobel Foundation", The Nobel Prize. Available at: http://www.nobelprize.org/nobel organizations/nobelfoundation/statutes.html (accessed on 20 February 2021).

Nobel Media AB (2019): "New translation of Alfred Nobel's will", The Nobel Prize. Available at: https://www.nobelprize.org/new-translation-of-alfred-nobels-will (accessed on 20 February 2021).

Norrby, Erling (2013): Nobel Prizes and Nature's Surprises, World Scientific Publishing, Hackensack.

University of Oxford (2020): "Academic integrity in research: Code of practice and procedure", University of Oxford (26 November 2020). Available at: http://www.admin. ox.ac.uk/personnel/cops/researchintegrity (accessed on 20 February 2021).

Rapoport, Sarah (2002): "Rosalind Franklin: Unsung Hero of the DNA Revolution", The History Teacher 36 (2002) 1, pp. 116, doi: https://doi.org/10.2307/1512499.

Rathi, Akshat (2017): “The Nobel Prize committee explains why women win so few prizes", Quartz (9 October 2017). Available at: https://qz.com/1097888/the-nobel-prizecommittee-explains-whywomen- win-so-few-prizes/ (accessed on 20 February 2021).

Rosser, Sue Vilhauer (2008): Women, Science, and Myth: Gender Beliefs from Antiquity to the Present, ABC-CLIO, Santa Barbara (CA).

Rossiter, Margaret W. (1982): Women Scientists in America: Struggles and Strategies to 1940, Johns Hopkins University Press, Baltimore (MD).

Sayre, Anne (2000): Rosalind Franklin and DNA, W. W. Norton and Company. Inc., New York.

Steneck, Nicholas H. (1994): "Research universities and scientific misconduct", Journal of Higher Education 65 (1994) 3, pp. 310-330, doi: https://doi.org/10.1080/00221546.19 94.11778503 .

24

Cf. the new translation of Alfred Nobel's will (Nobel Media AB, 2019).

25

This paper was produced as part of projects Bioetički standardi urbaniteta. Grad kao okvir etike života (s posebnim osvrtom na Rijeku) [Bioethical standards of urbanity. The city as a framework for the ethics of life (with special reference to Rijeka)], project leader Iva Rinčić (uniri-human-18-49), and
Novi trendovi u bioetici srednje i jugoistočne Europe: istraživanje $i$ umrežavanje resursa [New trends in the bioethics of Central and Southeast Europe: Research and networking of resources], project leader Amir Muzur (uniri-human-18-4-1130), financed by the University of Rijeka and in part supported by Croatian Science Foundation under the project IP-2020-02-7450. 
Watson, James D. (2001): The Double Helix. A Personal Account of the Discovery of the Structure of DNA, Scribner, New York.

Watson, James D. (2003): "Celebrating the genetic jubilee: a conversation with James D. Watson. Interviewed by John Rennie", Scientific American 288 (2003) 4, interview (led by John Rennie), pp. 66-69, doi: https://doi.org/10.1038/scientificamerican0403-66

Watson, James D.; Crick F. H. C. (1953): "Molecular Structure of Nucleic Acids: A Structure for Deoxyribose Nucleic Acid”, Nature 171 (1953), no. 4356, pp. 737-738.

White, Michael (2001): Rivals: Conflict as the Fuel of Science, Secker \& Warburg, London.

Wilkins, M. H. F.; Stokes, A. R.; Wilson, H. R. (1953): "Molecular Structure of Nucleic Acids: Molecular Structure of Deoxypentose Nucleic Acids", Nature 171 (1953), no. 4356, pp. 738-740.

Yakovchuk, Nadya; Badge, Joe; Scott, John (2011): "Staff and student perspectives on the potential of honour codes in the UK", International Journal for Educational Integrity 7 (2011) 2, pp. 37-52, doi: https://doi.org/10.21913/ijei.v7i2.762.

Yong, Ed (2017): "The Absurdity of the Nobel Prizes in Science", The Atlantic (3 October 2017). Available at: https://www.theatlantic.com/science/archive/2017/10/the-absurdityof-the-nobel-prizesin-science/541863/ (accessed on 20 February 2021).

Zallen, Doris T. (2003): “Despite Franklin's work, Wilkins earned his Nobel”, Nature 425 (2003), no. 6953, p. 15.

Zuckerman, Harriet (1996): Scientific Elite: Nobel Laureates in the United States, Transaction Publishers, New Brunswick (NJ) - London.

\title{
Toni Buterin, Iva Rinčić, Amir Muzur
}

\section{Iskren osvrt na Franklin - kako bi šezdesetgodišnji slučaj mogao spriječiti buduće nepravde}

\begin{abstract}
Sažetak
O ulozi Rosalind Franklin, kemičarke i rendgenske kristalografkinje, u jednom od najvažnijih otkrića 20. stoljeća - otkriću spiralne strukture DNK - već se dugo raspravlja. Premda su mnogi protagonisti ponudili različite inačice događaja koji su prethodili objavljivanju famoznog Watsonova i Crickova rada u časopisu Nature u travnju 1953. godine, svejedno je očigledno da je počinjeno teško kršenje istraživačke etičnosti. Analizirajući kontroverzu Franklinine zaslužene, ali nedobivene Nobelove nagrade, autori ovoga rada predlažu da bi se postupak nominiranja i dodjeljivanja Nobelove nagrade mogao revidirati da se izbjegnu buduće nepravde nalik Franklininoj. Po autorima, to bi se moglo postići povratkom k izvornoj ideji Alfreda Nobela o dodjeljivanju nagrade »onima koji su tijekom prethodne godine doprinijeli najvećoj dobrobiti čovječanstvu« ili dopuštajući da se preminulu osobu može i nominirati i nagraditi.
\end{abstract}

\section{Ključne riječi}

Rosalind Franklin, etika istraživanja, Nobelova nagrada, povijest DNK, nepravda 


\title{
Toni Buterin, Iva Rinčić, Amir Muzur
}

\section{Ein ehrlicher Rückblick auf Franklin - wie ein sechzigjähriger Fall zukünftige Ungerechtigkeiten abwehren könnte}

\begin{abstract}
Zusammenfassung
Über die Rolle von Rosalind Franklin, Chemikerin und Röntgenkristallografin, in einer der wichtigsten Entdeckungen des 20. Jahrhunderts - der Entdeckung der helikalen DNA-Struktur - wird geraume Zeit debattiert. Obgleich zahlreiche Protagonisten diverse Versionen der Ereignisse anboten, die der Veröffentlichung von Watsons und Cricks berühmtem Aufsatz in der Zeitschrift Nature im April 1953 vorausgingen, ist es nichtsdestoweniger offenkundig, dass ein schwerwiegender Verstoß gegen die Forschungsethik begangen wurde. Indem sie die Kontroverse um Franklins wohlverdienten, aber nicht erhaltenen Nobelpreis ergründen, legen die Verfasser dieser Arbeit nahe, dass der Prozess der Nominierung und Vergabe des Nobelpreises revidiert werden könnte, um künftigen, mit Franklins Fall vergleichbaren Ungerechtigkeiten aus dem Weg zu gehen. Den Autoren zufolge könnte dies erreicht werden, indem man auf Alfred Nobels ursprüngliche Idee zurückgreift, den Preis an diejenigen auszuhändigen, ,,die im vergangenen Jahr der Menschheit den größten Nutzen erbracht haben", oder indem man gestattet, Verstorbene sowohl zu nominieren als auch zu belohnen.
\end{abstract}

\section{Schlüsselwörter}

Rosalind Franklin, Forschungsethik, Nobelpreis, Geschichte der DNA, Ungerechtigkeit

Toni Buterin, Iva Rinčić, Amir Muzur

Évoquer sincèrement Franklin - comment un cas vieux de soixante ans pourrait éviter de futures injustices

\begin{abstract}
Résumé
Le rôle qu'a joué Rosalind Franklin, chimiste et cristallographe par rayons $X$, dans l'une des plus importantes découvertes du XXe siècle - découverte de la structure en double hélice de l'ADN - a déjà longuement été discuté. Bien qu'un grand nombre de protagonistes ait proposé diverses versions des faits ayant précédé la publication célèbre du travail de Watson et Crick dans la revue Nature en avril 1953, il est néanmoins évident qu'une grave violation des principes de l'éthique de la recherche a été commise. En analysant la controverse sur le prix Nobel mérité de Franklin, mais qui ne lui a pas été discerné, les auteurs de ce travail proposent de réviser la procédure de nomination et la remise du prix Nobel afin d'éviter de futures injustices semblables à celle dont a été victime Franklin. Selon les auteurs, cela pourrait se réaliser par le rétablissement de l'idée originelle d'Alfred Nobel en discernant les prix "à ceux qui ont contribué durant l'année précédente au plus grand bien-être de l'humanité » ou en permettant de nominer la personne défunte et de lui discerner un prix.
\end{abstract}

\section{Mots-clés}

Rosalind Franklin, éthique de la recherche, prix Nobel, histoire de l'ADN, injustice 